\author{
Egle Elena Šatait $\dot{e}^{*}$ \\ General Jonas Žemaitis Military Academy of Lithuania
}

\title{
Peace-Building Operations: The Case of Bosnia and Herzegovina
}

\begin{abstract}
Peace-building as one of the concepts of peace operations in general, recently is becoming more frequently analysed phenomena in political science and objectives and goals of peace-building more often becomes part of agenda and actions of international and nongovernmental organizations. Today peace-building became an integral part of missions conducted by United Nations (UN) and European Union (EU). These tendencies are evident in NATO too and the largest regional organization - Organization for Security and Co-operation in Europe (OSCE) - is active in early warning, conflict prevention, crisis management, post-conflict building. The purpose of the article is to analyse concept of peace-building and its measures, mechanisms used in peace operations. The first part of the article analyses how concept peace-building is analysed in UN, EU, OSCE and NATO by having an aim to show the language used by these organizations and what's the content of the terminology. The second part analyses peace-building operations in Bosnia and Herzegovina $(\mathrm{BiH})$, primary focusing on peace-building mechanisms used by UN, NATO, OSCE and EU. An example of $\mathrm{BiH}$ was chosen because of the state's importance both to the European Union and security in Europe as a whole and of special design of political system of the state after Dayton Agreement.
\end{abstract}

\section{Introduction}

Recently peace-building is becoming a_more frequently analysed phenomena in political science, and objectives and goals of peace-building more often become part of the agenda and actions of international and non-governmental organizations. Today peace-building missions become as important as preventive diplomacy, peacemaking and peacekeeping in United Nations (UN). The European Union (EU) by developing actively it's civilian capabilities and by implementing it's civilian missions, also pursues functions that academic sources characterise as peace-building. These tendencies are evident in NATO too. The largest regional organization - the Organization for Security and Co-operation in Europe (OSCE) - focus it's actions on early warning, conflict prevention, crisis management, and post-conflict building.

\footnotetext{
* Egle Elena Šataitè, M.A. is a lecturer of the Political Science Department of the General Jonas Žemaitis Military Academy of Lithuania. Address: Šilo str. 5a, LT-10322, Vilnius, Lithuania, tel. (85) 2103569, e-mail: eglesatas@yahoo.co.uk
} 
"The purpose of the article is to analyse the concept of peace-building and its measures and mechanisms used in peace operations. The evaluation of missions is not an aim of the article. The first part of the article analyses how the concept of peace-building is analysed in the UN, EU, OSCE and NATO by having an aim to show the language used by these organizations and what's the content of the terminology. The second part analyses peacebuilding operations in Bosnia and Herzegovina $(\mathrm{BiH})$, primary focusing on peace-building mechanisms used by the UN, NATO, OSCE and now the EU. The example of $\mathrm{BiH}$ was chosen because of the state's importance both to the European Union and security in Europe as a whole and because of the special design of the political system of the state after the Dayton Agreement. In the authors' opinion, the stability of $\mathrm{BiH}$ is one of the cornerstones of stability in all of Balkan region.

\section{Evolution and Content of the Term "Peace-Building"}

\subsection{Peace-Building on the United Nations agenda}

The term "peace-building" appeared on the United Nations political agenda with Agenda for Peace ${ }^{1}$ in year 1992. In this report by the Secretary-General among traditional functions of the $\mathrm{UN}$ - preventive diplomacy, peacemaking and peacekeeping ${ }^{2}$ - the concept "peace-building" was discussed for the first time. Agenda for Peace stated that one of the primary goals of the UN should be to rebuild "the institutions and infrastructures of nations torn by civil war and strife" and "in the largest sense, to address the deepest causes of conflict: economic despair, social injustice and political oppression".

In the context of United Nations, peace-building is understood as actions, by which the goals of peacemaking and peace-building are consolidated. Agenda for Peace outlines the basic means of peace-building: "disarming the previously warring parties and the restoration of order, the custody and possible des-

\footnotetext{
An Agenda for Peace. Preventive diplomacy, peacemaking and peace-keeping, http://www.un.org/Docs/ SG/agpeace.html, 20080814

2 Agenda for Peace describes these concepts as follows: Preventive diplomacy - is action to prevent disputes from arising between parties, to prevent existing disputes from escalating into conflicts and to limit the spread of the latter when they occur; Peacemaking - is action to bring hostile parties to agreement, essentially through such peaceful means as those foreseen in Chapter VI of the Charter of the United Nations; Peacekeeping is the deployment of a United Nations presence in the field, hitherto with the consent of all the parties concerned, normally involving United Nations military and/or police personnel and frequently civilians as well. Peace-keeping is a technique that expands the possibilities for both the prevention of conflict and the making of peace. For more see, for example, Ulozevičiūtė Ž., "Lithuania's Participation in International Peace Operations: Challenges of the NATO and EU Memberships", Lithuanian Annual Strategic Review 2004, p. 209 - 224, http://www.kam.lt/EasyAdmin/sys/files/strategic_review_2004_2.pdf
} 
truction of weapons, repatriating refugees, advisory and training support for security personnel, monitoring elections, advancing efforts to protect human rights, reforming or strengthening governmental institutions and promoting formal and informal processes of political participation".

In the case of international war, the United Nations recommends to develop not only economic and social projects, but also to enhance confidence between states, for example, to free travel, promote cultural exchanges, youth and educational projects, or simply to improve transportation or utilize resources such as water or electricity that they need to share.

In Agenda for Peace the United Nations also stresses that peace-building should be understood as an integral part of preventive diplomacy. When conflict breaks out and peacemaking and peace-keeping come into play, projects that address economic, social, cultural and humanitarian problems should follow. That is peace-building.

After two years in Agenda for Development concept of peace-building was developed in more detailed and is presented as one of the preconditions for development. Peace-building is related to economic, social, cultural development in the agenda. Means of peace-building are understood as actions "to identify and support structures which will tend to strengthen and solidify peace in order to avoid a relapse into conflict" ${ }^{\prime \prime}$. Agenda outlines basic goals of peace-building: establishment of new or development of existing political, social, judicial institutions, land reform or other measures of social justice, demobilization and defence reform. Agenda also stresses that one of primary goals of peace-building should be food aid, support for health systems, the clearance of mines and logistical support for essential organizations in the field. Another goal according to Agenda should be re-integration of combatants, which have been recruited at the very young age, into society.

It should be stressed, that both in Agenda for Peace and in Agenda for Development peace-building is associated with the re-building of regions after conflicts. For example, Agenda for Development points out that "preventive diplomacy aims to prevent the outbreak of conflict, peace-building starts during the course of a conflict to prevent its recurrence" ${ }^{4}$.

Whereas in the Supplement To An Agenda For Peace: Position Paper Of The Secretary-General On The Occasion Of The Fiftieth Anniversary Of The United Nations ${ }^{5}$ of year 1995 Secretary-General stresses that peace-building "can also support preventive diplomacy" - "demilitarization, the control of small arms, institutional reform, improved police and judicial systems, the monitoring of human rights, electoral reform and social and economic development can be as valuable in preventing conflict as in healing the wounds after conflict has occurred".

\footnotetext{
${ }_{3}^{3}$ An Agenda for Development, http://daccessdds.un.org/doc/UNDOC/GEN/N94/209/22/IMG/N9420922. pdf?OpenElement, 20080814.

${ }^{4}$ Ibid.

${ }^{5}$ Supplement To An Agenda For Peace: Position Paper Of The Secretary-General On The Occasion Of The Fiftieth Anniversary Of The United Nations, http://www.un.org/Docs/SG/agsupp.html, 20080814.
} 
Failures of the United Nations in Rwanda and Somali where followed by the so-called Brahimi report in the year 2000, in which the use of peacebuilding not only in post-conflict phase is also stressed. At that time, it was suggested to use peace-building means as a follow-on to other peace operations in Tajikistan and Haiti, and as independent initiatives in Guatemala and Guinea-Bissau ${ }^{6}$. As the aim of Brahimi report was to evaluate UN peace operations and to give recommendations, peace-building was not an exception. According to the Report, more emphasis should be given to such goals like support in elections, reform, restructuring and training of the police, training military, police and other civilian personnel on human rights issues and on the relevant provisions of international humanitarian law, disarmament, demobilization and reintegration of former combatants. The Brahimi report both in terms of scope and relevance stressed the meaning of all four concepts - preventive diplomacy, peacemaking, peacekeeping and peace-building - on the United Nations agenda and practice.

In the year 2005 the Secretary-General published In larger freedom. In this report issues of peace operations were also addressed. Kofi Annan had to admit the mediation and implementation of peace agreements has failed a few times in 1990s and such countries like Angola, Rwanda, and Somali had lapsed back into violence. He stated that:

If we are going to prevent conflict we must ensure that peace agreements are implemented in a sustained and sustainable manner. Yet at this very point there is a gaping hole in the United Nations institutional machinery: no part of the United Nations system effectively addresses the challenge of helping countries with the transition from war to lasting peace. I therefore propose to Member States that they create an intergovernmental Peace-building Commission, as well as a Peace-building Support Office within the United Nations Secretariat, to achieve this end ${ }^{8}$.

A few months later the Secretary-General issued an Explanatory Note by Secretary-General on the Peace-building Commission, Addendum to Report of the Secretary-General, In larger freedom: towards development, security and human rights for all $^{9}$ where purposes and functions of Peace-building Commission were described. According to the report and Resolution 1645 of the General Assembly, Commission should focus on conflict prevention and post-conflict recovery: "provide necessary information to the Security Council and focus attention on development and institution-building efforts necessary for recovery", ensure financing for recovery and development activities, and

\footnotetext{
${ }^{6}$ Report of the Panel on United Nations Peace Operations, http://daccessdds.un.org/doc/UNDOC/GEN/ N00/594/70/PDF/N0059470.pdf?OpenElement, 20080816.

${ }^{7}$ Ibid.

${ }^{8}$ In Larger Freedom: towards development, security and human rights for all, http://daccessdds.un.org/doc/ UNDOC/GEN/N05/270/78/PDF/N0527078.pdf?OpenElement, 20080817.

${ }^{9}$ Explanatory Note by Secretary-General on the Peace building Commission, Addendum to Report of the Secretary-General, In larger freedom: towards development, security and human rights for all, http:// daccessdds.un.org/doc/UNDOC/GEN/N05/356/07/PDF/N0535607.pdf?OpenElement, 20080818.
} 
periodically review progress ${ }^{10}$. The Peace-building Commission ${ }^{11}$ works on three principal configurations - Organizational Committee, Country Specific Meetings, Working Group on Lessons Learned - and operates resources and proposes strategies for post-conflict recovery. According to Resolution 1645, Organizational Committee brings together 31 member states: seven members selected by the Security Council ${ }^{12}$, seven members elected by the Economic and Social Council ${ }^{13}$, five of the top providers of assessed contributions to United Nations budgets and of voluntary contributions to the United Nations funds, programmes and agencies, including a standing peace-building fund ${ }^{14}$, five top providers of military personnel and civilian police to United Nations missions ${ }^{15}$ and seven members elected by the General Assembly ${ }^{16}$. The main function of the Organizational Committee is to establish the work agenda, including the establishment of the medium-term calendar for the Commission's wide-ranging activities, and development of Integrated Peace-building Strategies. Country Specific Meetings of the Peace-building Commission looks at issues particular to individual focus countries. Today three countries - Burundi, Guinea-Bissau and Sierra Leone - are on the agenda.

Special attention of the United Nations to peace-building is also evident from the fact that together with the Peace-building Commission, the Peace-building Fund and Peace-building Support Office were established to strengthen the peace-building activities of the UN.

The United Nations Peace-building Fund was launched on October 2006 at the request of General Assembly and Security Council for post-conflict peace-building. The aim of the Fund is to support direct and immediate interventions to the peace-building process, especially when no other funding mechanisms are available ${ }^{17}$. The role of the Fund is to support implementation of peace agreements, efforts of countries in building and strengthening capacities, which help to resolve the conflict, establishment or re-establishment of essential administrative services, related human and technical capacities, and participate in critical interventions designed to respond to imminent threats to the peace-building process (e.g., the reintegration of ex-combatants disarmed under a disarmament, demobilization and reintegration programme) ${ }^{18}$.

\footnotetext{
${ }^{10}$ Ibid.

${ }^{11}$ According to Resolution 1645 the purposes of the Commission are: to bring together all relevant actors to marshal resources and to advise on the proposed integrated strategies for post conflict peace-building and recover; to help ensure predictable financing for early recovery activities and sustained financial investment over the medium to long-term; to develop best practices on issues in collaboration with political, security, humanitarian and development actors.

${ }^{12}$ Belgium, China, France, the Russian Federation, South Africa, the United Kingdom of Great Britain and Northern Ireland, and the United States of America in 2008.

${ }^{13}$ Angola, Brazil, the Czech Republic, Guinea-Bissau, Indonesia, Luxembourg and Sri Lanka in 2008.

${ }^{14}$ Canada, Germany, Japan, the Netherlands and Sweden in 2008.

${ }^{15}$ Bangladesh, Ghana, India, Nigeria and Pakistan in 2008.

${ }^{16}$ Burundi, Chile, Egypt, El Salvador, Fiji, Georgia and Jamaica in 2008.

${ }^{17}$ Peacebuilding Fund: Terms of Refference, http://www.unpbf.org/beta/docs/TOR.pdf, 20080820.

${ }^{18}$ Ibid.
} 
The budget of the Peace-building Fund is distributed into three "windows": Peace-building Fund Window I includes countries that are on the agenda of the Peace-building Commission, Peace-building Fund Window II includes countries that have been designated by the United Nations Secretary-General, and under exceptional circumstances, the Fund can disburse emergency funding - Peace-building Fund Window III, this facility is activated at the request of the Senior UN Representative in the country. In September 2008 four countries Burundi, Central African Republic, Guinea-Bissau and Sierra Leone - received support from Peace-building Fund under Window I; five countries receive support under Peace-building Fund under Window II - Comoros, Cōte d'Ivoire, Guinea, Liberia, and Nepal. Under Peace-building Fund Window III projects are funded in Burundi, Central African Republic, Cōte d'Ivoire, Guinea, Haiti, Liberia and Kenya ${ }^{19}$.

However Jeniffer M. Hazen in article "Can Peacekeepers be Peacebuilders" ${ }^{\prime 20}$ makes a conclusion that peace-building in UN context remained a largely amorphous concept, because in most cases goals of peacekeeping, for example, institutional reform, are interrelated with the goals of peace-building and the even United Nations itself declare that peace-building should be integral part of peacekeeping.

\subsection{European Union and Civilian Crisis Management}

Attempts of European Union member states to be active in peace operations should be dated to Sent-Malo agreement in 1998, when after tragedy in Bosnia both United Kingdom and France started changing positions on common security and defence policy of the EU. It was stated that the EU has to play its full role in the international arena and to this end it "must have the capacity for autonomous action, backed by credible military forces, the means to decide to use them, and a readiness to do so, in order to respond to international

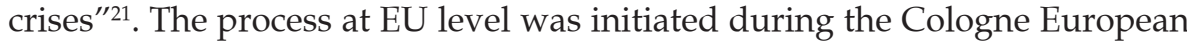
Council in 1999, where in the wake of crisis in Kosovo member states started Europeanization process of Sent-Malo agreement. At Helsinki European Council meeting in 1999, EU member states set a military capability target known as the Headline Goal 2003, whereas Feira European Council in 2000 and Goteborg European Council in 2001 focused on civilian capabilities.

Both military and civilian capabilities are being developed for missions assigned in article 17.2 of the Treaty on European Union and known as Peters-

\footnotetext{
${ }^{19}$ United Nations Peace-building Fund, Bulletin No. 4, http://www.unpbf.org/index.shtml, 20080820.

${ }^{20}$ Hazen J. M., „Can Peacekeepers be Peace-builders?”, International Peacekeeping, vol. 14., no. 3, 2007, p. 324.

21 "British-French summit St-Malo, 3-4 December 1998, From St-Malo to Nice. European defence: core documents", Chaillot Paper 47, May 2001, p. 8-9, http://www.iss.europa.eu/uploads/media/cp047e.pdf, 20080821
} 
berg tasks: humanitarian and rescue tasks; peacekeeping tasks; tasks of combat forces in crisis management, including peacemaking. However, as Jean-Yves Haine argues, there were a series of successful interpretations of this legal definition, for example, in Cologne in 1999 it was stated that these tasks include "the full range of conflict prevention and crisis management tasks" ${ }^{22}$. In sum, EU actions can take many forms from peacemaking to peacekeeping, from "the most modest to the most robust", as Martin Ortega put it ${ }^{23}$. European Security Strategy helped to clarify types of peace operations that the EU should be involved in. It identified five major threats: terrorism, proliferation of weapons of mass destruction, regional conflicts, state failure and organised crime. EU member states also stated that:

Our traditional concept of self- defence - up to and including the Cold War - was based on the threat of invasion. With the new threats, the first line of defence will often be abroad. The new threats are dynamic. The risks of proliferation grow over time; left alone, terrorist networks will become ever more dangerous. State failure and organised crime spread if they are neglected - as we have seen in West Africa. This implies that we should be ready to act before a crisis occurs." Conflict prevention and threat prevention cannot start too early [underlined by author - E. E. S. S. $]^{24}$.

As Haine argues, this means that the EU is capable of being involved in stability and nation-building ${ }^{25}$. In the case of EU, it means the use of peace-building mechanisms, for example, police and/or civil administration personnel, and/or civil protection capabilities.

In the case of military capabilities, member states agreed to be able to deploy 50,000 - 60,000 troops, within 60 days and be sustainable for a year in support of the Petersberg Tasks by the end of 2003. At Laeken European Council in 2001 heads of states declared that is capable to conduct some crisis-management operations ${ }^{26}$. This position was reinforced at the May 2003 General Affairs and External Relations Council and Thessaloniki European Council in June 2003, which stated that "the EU now has operational capability across the full range of Petersberg tasks, limited and constrained by recognised shortfalls"27. By stressing that interoperability, deployability and sustainability should be at the core of member states efforts and in the light of European Security

\footnotetext{
${ }^{22}$ Haines J.-Y., "An Historical Perspective”, in Gnesotto N., ed., EU Security and Defence Policy. The First Five Years (1999-2004), p. 44, http://www.iss.europa.eu/uploads/media/5esdpen.pdf, 20080821.

${ }^{23}$ Ortega M., "Beyond Petersberg: missions for the EU military forces", in Gnesotto N., ed., EU Security and Defence Policy. The First Five Years (1999-2004), p. 74, http://www.iss.europa.eu/uploads/media/5esdpen. pdf, 20080821.

${ }^{24}$ A Secure Europe in a Better World, European Security Strategy, http://www.consilium.europa.eu/uedocs/ cmsUpload/78367.pdf, 20080801.

${ }^{25}$ Haines, (note 22) p. 51.

${ }^{26}$ Council of the European Union, Presidency Conclusions, European Council Meeting in Laeken, 14-15 December 2001, http://www.consilium.europa.eu/ueDocs/cms_Data/docs/pressData/en/ec/68827.pdf, 20080822.

${ }^{27}$ Council of the European Union, Presidency Conclusions, Thessaloniki European Council, 19-20 June 2003, http://www.consilium.europa.eu/ueDocs/cms_Data/docs/pressData/en/ec/76279.pdf, 20080822.
} 
Strategy, Brussels European Council in 2004 endorsed Headline Goal $2010^{28}$. The key element of HG 2010 is the creation of rapid reaction forces, which will allow the EU to react to all spectrums of crisis management operations covered by the Treaty. Rapid response was already discussed in Helsinki as an important aspect of EU crisis management capabilities and after successful operation Artemis in June 2003 it's development started. On 1 January 2007 the EU Battlegroups reached full operational capability. The battlegroup is the minimum militarily effective, credible, rapidly deployable, coherent force package capable of stand-alone operations, or of being used for the initial phase of larger operations. The battlegroups are about 1,500 personnel strong. The battlegroups are sustainable for 30 days in initial operations, extendable to 120 days, if re-supplied appropriately. Battlegroups will be employable for Petersberg tasks and those tasks identified in the European Security Strategy, in particular in tasks of combat forces in crisis management. As a part of capability development process, EU worked out five illustrative scenarios for the use of Battlegroups: conflict prevention, separation of parties by force, stabilisation, reconstruction and military advice to third countries, evacuation operations and assistance to humanitarian operations ${ }^{29}$. Battlegroups generally being part of military component of ESDP is also envisaged of conducting peace-building tasks, e.g. conflict prevention, reconstruction and military advice.

In the case of civilian capabilities, the capacity to develop and deploy civilian police missions was discussed in Helsinki. Later, in Feira, the European Council in June 2000, member states listed four priority areas in which the Union intended to acquire concrete capabilities: police cooperation, strengthening the rule of law, civilian administration, and civil protection. In Feira member states were called to develop the capacity to provide up to 5,000 police officers (from which up to 1,000 police officers within 30 days) by $2003^{30}$. Civilian Headline Goal was also developed in "Goteborg European Council in June 2001. The summit set concrete targets for the other three priorities identified in Feira. Member states have undertaken to provide 200 officers (prosecutors, judges, prison officers) in charge of crisis management operations in area of strengthening the rule of law. These types of missions are envisaged to address shortfalls of legal systems in countries where, for example, incompetent judges, widespread corruption and/or laws do not meet international standards, especially in area of human rights, endanger international peace and security. As a last resort such missions may even replace personnel of the legal system with international judges, legal experts, court officers and support staff. Still it's more likely that the EU will help to improve the functioning of the local

\footnotetext{
${ }^{28}$ Council of the European Union, Presidency Conclusions, Brussels European Council, 17-18 June 2004, http://www.consilium.europa.eu/uedocs/cmsUpload/81742.pdf, 20080822.

${ }^{29}$ EU Council Secretariat, Factsheet. EU Battlegroups, February 2007, http://www.consilium.europa.eu/ uedocs/cmsUpload/Battlegroups February 07-factsheet.pdf, 20080823.

${ }^{30}$ Council of the European Union, Presidency Conclusions, Santa Maria da Feira European Council, 1920 June 2000, http://www.consilium.europa.eu/ueDocs/cms_Data/docs/pressData/en/ec/00200-r1.en0. htm, 20080823.
} 
judicial system and will focus on monitoring, mentoring, training officials and assisting the government in reforming laws and the legal system ${ }^{31}$. For example, the EU mission in Georgia EUJUST THEMIS assisted by developing a strategy for reforming Georgian criminal legislation. In the case of civilian administration, member states promised to contribute personnel to a pool of experts, who would be capable of accepting civilian administration missions in the context of crisis management operations and if necessary being deployed at very short notice; functions of civilian administration missions can be establishment or guaranteeing elections, education, water provision, etc. Civil protection consists of three components: 1) 2 or 3 assessment and/or coordination teams, capable of being mobilised around the clock and consisting of 10 experts who could be dispatched within 3 to 7 hours; 2 ) intervention teams of up to 2000 persons for deployment at short notice; 3) additional or more specialised means which could be dispatched within 2 to 7 days depending on the particular needs of each crisis. Civil protection missions are designed to deal with victims of natural, technical and environmental disasters in situations marked by political violence. Civil protection mechanisms can also be used to support a coordinated EU approach to search and rescue operations, the construction of refugee camps and provision of humanitarian aid ${ }^{32}$. As for today, member states are able to provide 5,761 policemen, 631 officers for strengthening the rule of law mission, 565 staff for civilian administration missions, 579 civil protection experts and 4445 staff of intervention teams for civil protection missions ${ }^{33}$.

At the request of the PSC, the Council Secretariat simultaneously worked on the concept and wider use of monitoring missions. This question became important after EU monitoring missions in Balkans. During May 2003 the PSC prepared the Concept for EU Monitoring Missions. This document described monitoring missions as a generic tool, which would be used in all different phases of crisis management - conflict prevention/resolution and/or crisis management and/or peace-building - and "consists of a mission whose primary activity is to observe, monitor and report to the sending organisation on the general and security situation in the host country or in relation to specific agreement ${ }^{\prime \prime 34}$. It also includes such activities as contribution in confidence building, low-level conflict resolution, border monitoring, monitoring of refugee returns, human rights monitoring, monitoring of disarmament and demobilisation, and rule of law issues. Member states have committed 505 personnel to monitoring missions.

\footnotetext{
${ }^{31}$ Merlingen M. with Ostrauskaite R., European Union Peace-building and Policing, Routledge, 2006, p. 47.

${ }^{32}$ Ibid., p. 46-47.

${ }^{33}$ EU Council Secretariat, European Security and Defence Policy: the civilian aspects of crisis management, May 2007, http://www.consilium.europa.eu/uedocs/cmsUpload/Background_JPO_2007-Civilian_aspects_compressed.pdf, 20080823.

${ }^{34}$ Nowak A., „Civilian Crisis Management within ESDP”, in Nowak A., ed., Civilian Crisis Management: the EU Way, Chaillot paper 90, June 2006, p. 28, http://www.iss.europa.eu/uploads/media/cp090.pdf, 20080823.
} 
The execution of Petersberg tasks is entrusted to ESDP institutions and mechanisms. The key political decisions are taken at the highest Council levelEuropean Council and General Affairs and External Relations Council (GAERC). In addition, Helsinki European Council set up three bodies - Political and Security Committee (PSC), European Union Military Committee (EUMC) and European Union Military Staff (EUMS). PSC is the principal decision-shaping body, but as Antonio Missiroli notes it's decision making role is limited, because for political/strategic decisions it relies on the GAERC and financial aspects of CFSP/ESDP is still the matter of COREPER ${ }^{35}$. Through PSC both military and civilian crisis management decisions are channelled. It is also linked with the High Representative for the CFSP and the EU Special Representatives in order to ensure full political control and strategic direction to all ESDP missions. EU Military Committee is composed of the Chiefs of Defence, who are regularly represented by their permanent military representatives. It gives military advice and recommendations to the PSC and its Chairman attends Council meetings when decisions with defence implications are to be taken. EUMS is part of the Council Secretariat and works under the direction of the EUMC. It provides military expertise and support to ESDP, including the conduct of crisis management operations, early warning, situation assessment and strategic planning for the military aspects of Petersberg tasks.

Decisions concerning institutions in the civilian field were taken at the European Council in Lisbon in March 2000. Member states agreed to create the Committee for the Civilian Aspects of Crisis Management (CIVCOM). Its main function is to advice the PSC on the civilian aspects of EU and member states crisis management activities. It's inter-pillar institution that operates under COREPER and gives advice to the PSC on Second Pillar and Member States' crisis management activities and helps to ensure a higher degree of inter-pillar coherence ${ }^{36}$. CIVCOM is also part of the mechanism for the exchange of information and coordination between the EU and it's member states to facilitate rapid reaction. Still it's role remains of an advisory character - it formulates recommendations to the PSC that has a central role to play in the definition and follow-up of the EU's response to a crisis, as Agnieszka Nowak summarises ${ }^{37}$.

To strengthen the civilian aspects of ESDP missions, in an informal meeting in Hampton Court in 2005 EU member states decided to create The Civilian Planning and Conduct Capability (CPCC) and to establish the position of Civilian Operations Commander. It's regarded as new civilian equivalent to the EUMS. Established in August 2007, CPCC is located in Brussels and is part of the Council General Secretariat. The CPCC has a mandate to plan and conduct civilian ESDP missions, under the political control and strategic

\footnotetext{
${ }^{35}$ Missiroli A., "ESDP- How it works", in Gnesotto N., ed., EU Security and Defence Policy. The First Five Years (1999-2004), p. 64, http://www.iss.europa.eu/uploads/media/5esdpen.pdf, 20080823.

${ }^{36}$ Preparatory document related to CESDP : Establishment of a European Union Committee for Civilian Crisis Management, http://www.consilium.europa.eu/uedocs/cmsUpload/Preparatory\%20document\%20 CESDP\%20-\%20Committee.pdf, 20080823.

${ }^{37}$ Nowak, (note 34) p. 23.
} 
direction of the PSC, to provide assistance and advice to the SG/HR, the Presidency and the relevant EU Council bodies and to direct, coordinate, advise, support, supervise and review civilian ESDP operations. The CPCC Director, as EU Civilian Operations Commander, exercises command and control at the strategic level for the planning and conduct of all civilian crisis management operations, under the political control and strategic direction of the PSC and the overall authority of the SG/HR ${ }^{38}$. CPCC is responsible for nine missions in the areas of police, border assistance management, rule of law and security sector reform as for today: EUPM (Bosnia \& Herzegovina); EULEX KOSOVO; EUPOL COPPS and EUBAM Rafah (Palestinian Territories); EUJUST LEX (for the Iraqi justice system); EUPOL Afghanistan; EUPOL RD Congo; and EU SSR Guinea-Bissau (it's the first mission entirely planned by CPCC) and European Union Monitoring Mission in Georgia (EUMM).

In sum, in a short time the European Union made considerable progress in framing and implementing both military and civilian capabilities of ESDP. Lately special attention has been given to develop further civilian capabilities, examples of which are creation of CPCC and Headline Goal 2010 for civilian capabilities. Pedro Serrano ${ }^{39}$ argues that EU missions can be categorised as follows:

- Stabilisation (military force is deployed to separate of warring parties/ factions or the impose of maintenance of peace in an area affected by conflict; operations Althea in BiH and Artemis in the Democratic Republic of Congo are good examples of such operations);

- Substitution (international components are required to take over direct management of responsibilities which in normal circumstances are under control of the local authorities, e.g. in the security sector (military, police), area of rule of law (judiciary, prosecutors, penal system);

- Strengthening or reform (the aim is to reform/reconstruct/construct particular branch of state activity through monitoring and mentoring, also inspection; it's done in defence or police fields, can also be extended to rule of law and public administration; examples of such missions are police mission in BiH (EUPM), police mission in FYROM (Proxima), rule of law mission in Georgia (EUJUST Themis), police mission in Democratic Republic of Congo (EUPOL Kinshasa));

- Monitoring (supervision the implementation of an agreement, for example, like in the Aceh Monitoring Mission (AMM) and the EU Border Assistance Mission at Rafah Crossing Point in the Palestinian Territories (EUBAM Rafah));

- Support to crisis management organisations (support of crisis management efforts led by UN, OSCE, AU, etc.).

\footnotetext{
38 "Introducing CPCC", ESDP newsletter, No. 6, July 2008, p. 24 -45, http://www.consilium.europa.eu/ uedocs/cmsUpload/pages24-25-CEU8003ESDP6final_vers.pdf, 20080825.

${ }^{39}$ Serrano P., "A Strategic Approach to the European Security and Defence Policy", in Nowak A., ed., Civilian Crisis Management: the EU Way, Chaillot paper 90, June 2006, p. 39-43, http://www.iss.europa.eu/ uploads/media/cp090.pdf, 20080823.
} 
It should be noted that even until today the EU uses mostly one term civilian crisis management - to describe many activities EU personnel can be tasked with. Civilian crisis management is described as the intervention of civilian personnel in a crisis having a task to prevent its escalation and to solve it. Civilian and even military EU capabilities, e.g. EU Battlegroups, now have a task to be involved in peace-building as it is understood as a means to prevent from subsequent crises. For the first time this question was discussed in roundtable discussion in Washington D.C. in 2001. In the report of the discussion European Approaches to Civilian Crisis Management ${ }^{40}$ Chris Lindborg notes that experts make distinction between "conflict prevention" - activities that take place before any hostilities have occurred - and "crisis management" - intervention only after violence has erupted. Using UN language, the EU should be engaged in preventive diplomacy and peacemaking activities. Lindborg also emphasises that "post-conflict peace building is seen as another means of preventing subsequent crises", and therefore frequently becomes part of civilian crisis management discussions as well. Lindborg makes a conclusion that civilian crisis management "is comprised of multiple stages and multiple actors; and the lines between CCM and conflict prevention on the one hand, and between civilian and military crisis management on the other hand, are not clearly defined".

While looking at EU missions conclusion that EU is focusing on preventive actions and peace-building can be made. Today the EU conducts 12 missions in the Western Balkans (3 missions), South Caucasus (1 mission), Middle-East (3 missions), Asia (1 mission), and Africa (4 missions) ${ }^{41} .8$ missions are civilian (EU Police Mission in Bosnia-Herzegovina (EUPM), European Union rule of law mission in Kosovo (EULEX KOSOVO), European Union Monitoring Mission (EUMM) in Georgia, EU Police Mission in the Palestinian Territories (EUPOL COPPS), EU Border Assistance Mission at Rafah Crossing Point in the Palestinian Territories (EU BAM Rafah), EU Integrated Rule of Law Mission for Iraq (Eujust Lex), EU Police Mission in Afghanistan (EUPOL AFGHANISTAN), EUPOL RD CONGO), 2 - military (EU Military Operation in Bosnia and Herzegovina (EUFOR-Althea, EUFOR TCHAD/RCA) and 2 civilian - military (EU mission in support of Security Sector Reform in Guinea-Bissau (EU SSR Guinea-Bissau), EU security sector reform mission in the Democratic Republic of the Congo (EUSEC RD Congo) according to the language of the EU. Almost all civilian EU mission can be described as peace-building missions. EUPOL RD Congo has a mission to help Congolese Police in its reform efforts and supports all its possible interactions with the judicial system. 39 international staff are now deployed on the ground with the support of 9 local. EUPOL Afghanistan aims at contributing to the establishment of sustainable and effective civilian

\footnotetext{
${ }^{40}$ European Approaches to Civilian Crisis Management. A Basic Special Report on Roundtable Discussions Held in Washington, D.C., October 2001, British American Security Information Council, 2002, http:// www.basicint.org/pubs/Research/2002ccm.pdf, 20080826.

${ }^{41}$ Data as of September 2008.
} 
policing arrangements under Afghan ownership and in accordance with international standards. The mission is monitoring, mentoring, advising and training at the level of the Afghan Ministry of Interior, regions and provinces. Mission strength is 184 international and 90 local staff. EUJUST LEX in Iraq provides training and professional development opportunities to senior Iraqi judiciary, police and penitentiary officials. The new EU mission in Georgia EUMM Georgia also supports the hypothesis that civilian missions are peace-building operations. After and agreement between Georgia and Russia was reached, the EU sent 200 civilian observers to monitor and analyse the situation.

\subsection{Peace - Building Operations in NATO Framework}

NATO very briefly outlines what type of missions organisations should be involved in. During the Cold War NATO's basic task was to ensure that the Alliance had the capacity to deal with collective defence operations under Article 5 of the North Atlantic Treaty. After the Cold War, the Alliance is involved in conflict prevention, restoration and preservation of peace operations, for example, in former Yugoslavia, Afghanistan and Iraq. NATO led operations can be categorized in two types: crises response operations and peace support operations. Crises response operations - NATO-led non-Article 5 of the North Atlantic Treaty operations that include rendering support to civilian authorities, humanitarian, sanctions/embargo implementation and peace support operations. Peace support operations - NATO-led operations covering conflict prevention, peace making, peacekeeping, peace enforcement and peace building operations ${ }^{42}$. In the language of NATO both types of operations are called crisis management operations, in which military and non-military measures can be used. NATO's mission in Afghanistan, International Security Assistance Force (ISAF) is one of the examples how military and civilian tasks are combined in one operation. NATO declares that its task is to help the Government of Afghanistan to extend and exercise its authority and influence across the country, create conditions for stabilisation and reconstruction, but at the same time reconstruction and development is an integral part of ISAF mission, mostly fulfilled through 26 Provincial Reconstruction Teams, composed of military and civilian personnel, with the task for the latter one to engage in peace-building activities. These peace-building activities include: rehabilitation of schools and medical facilities (in 2001 8\% of Afghans had access to basic healthcare, whereas in early 2007 the figure is up to $83 \%$, in 2001 only 1.2 million children attended school daily and today 7 million do, including 2 million girls, plus about 45,000 teachers were trained in 2006), the restoration of water supplies,

\footnotetext{
${ }^{42}$ Ministry of Defence of Lithuania, "Tarptautinių operacijų apibrèžimai” [Definitions of International Peace Operations], http://www.kam.lt/index.php/lt/144614/, 200810 11;Ulozevičiūte Ž., Lithuania’s Participation in International Peace Operations: Challenges of the NATO and EU Memberships, Lithuanian Annual Strategic Review 2004, Vilnius, 2005, p. 209 - 224.
} 
reconstruction of roads, cleaning territories from mines (88,136 anti-personnel mines and 11,524 anti-tank mines are already destroyed), demobilization and reintegration of ex-combatants (about 60,000 ex-combatants disarmed and reintegrated, 35,000 - 40,000 officers are serving in the new national police force, 30,000 soldiers are serving in the new national army), restitution of refugees (4.8 million have returned so far (3.5 million with the UN's help) $)^{43}$. NATO's mission in Iraq should be also described as having peace-building mode as the main aim is to train Iraqi military personnel, support the development of the country's security institutions, and coordinate the delivery of equipment. In Afghanistan peace-building is conducted by both military and civilian personnel, whereas in Iraq military is responsible for the mission, but both these case should be regarded as having peace-building mode as it's related to the reconstruction and development of countries and includes classical instruments of peace-building.

\subsection{OSCE and Peace - Building}

Peace-building is also an instrument used by regional organizations. Organization for Security and Co-operation in Europe (OSCE) is the largest regional security organization in the world having 56 member states from Europe, Central Asia and North America. OSCE is active in three dimensions of security - the politico-military, the economic and environmental, and the human dimension. It therefore addresses a wide range of security-related concerns, including arms control, confidence - and security-building measures, human rights, national minorities, democratization, policing strategies, counter-terrorism and economic and environmental activities. So it can be stated that OSCE uses mechanisms of early warning, conflict prevention, crisis management and post-conflict building.

As far as it concerns political-military dimension, OSCE is active in arms control (helps to stop the spread of weapons and offers assistance with their destruction), border management (actions range from conflict prevention to post-conflict management, capacity-building and institutional support), combating terrorism, conflict prevention, military reform (OSCE's Forum for Security Co-operation provides a framework for political dialogue on military reform, practical activities are conducted by the field operations), policing. In the economic and environmental dimension OSCE is active in fight against anti-trafficking, promotion of economic activities (combating money laundering and the financing of terrorism, promoting good governance, supporting transport development and security, assisting migration management), also environmental activities. Human dimensions of OSCE activities is related to fight against trafficking, promotion of democracy, human rights, minority

${ }^{43}$ NATO in Afghanistan. Reconstruction and development. June 2007, http://www.nato.int/issues/afghanistan/ factsheets/reconst_develop.html, 20080828. 
rights, freedom of media, tolerance, rule of law, gender equality, education, assistance in elections. All these activities should be regarded as peace-building mechanisms. It also shows how many different forms it can take: from police functions to military reform, from combating money laundering to promotion of good governance, from promotion of human rights to assistance in elections. For example, the OSCE Office in Baku has the tasks to carry-out legislative reforms in the fields of elections, mass media, civil society, to train police and penitentiary officers and others.

\section{Peace-Building Efforts in Bosnia and Herzegovina}

There are many explanations for the failure of the international community to prevent or stop the wars in the former Yugoslavia - lack of cohesion in EU, unwillingness of governments to provide adequate resources, short-termism of politicians. Mary Kaldor in the book, New \& Old Wars Organized Violence in a Global Era ${ }^{44}$ argues that international community failed to understand why or how the war was fought. Politically and military, author says, war was perceived as a conflict between competing nationalisms of a traditional essentialist type and this was true both in Europe and USA, but such understanding missed the point that this was a conflict between a new form of ethnic nationalism and civilized values. The international community fell into the nationalist trap and contributed to the nationalist goals. Even ethnic cleansing was treated as a side-effect of war.

In the most constituent republics of Yugoslavia nationalists parties gained power through democratic elections in 1991 and formed coalition government despite having conflicting goals: Muslim nationalists want a centralised independent Bosnia, Serb nationalists want to stay in Belgrade-dominated rump Yugoslavia, Croats want to join an independent Croatian state ${ }^{45}$. Governments of Croatia and Slovenia also called for the transformation of Yugoslavia into loose federation or confederation, while Serbia favoured more centralized state. This led to radicalization of nationalists sentiments and Croatia and Slovenia proclaimed it's independence in $1991^{46}$. The first parliamentary elections in $\mathrm{BiH}$ in 1991 led to a national assembly dominated by three ethnically-based parties, which had formed a loose coalition to oust the communists from power. Croatia's and Slovenia's declarations of independence and the war that followed in Croatia starting from 1991 when Serbian rebels backed by Yugoslav military dominated by Serbs proclaimed secession of parts of Croatia with

${ }^{44}$ Kaldor M., New \& Old Wars. Organized Violence in a global era, Polity, 2001, p. 57-58.

${ }^{45}$ Timeline: Bosnia-Hercegovina, http://news.bbc.co.uk/2/hi/europe/country_profiles/1066981.stm, 2008 0902.

${ }^{46}$ Merlingen, (note 31) p. 53 
having a pretext to protect the Serbian minority in Croatia, placed $\mathrm{BiH}$ and its three constituent nations - Bosniaks (until 1994 called Muslims), Serbs and Croats - in an awkward position. A significant split soon developed on the issue of whether to stay within the Yugoslav federation (overwhelmingly favoured among Serbs) or seek independence (overwhelmingly favoured among Bosniaks and Croats). The Serb members of parliament, consisting mainly of the Serb Democratic Party members, abandoned the central parliament in Sarajevo, and formed the Assembly of the Serb People of BiH on 24 October 1991, which marked the end of the tri-ethnic coalition that governed after the elections in 1991. This Assembly established the Serbian Republic of BiH on 9 January 1992, which became Republika Srpska in August 1992. A declaration of $\mathrm{BiH}$ sovereignty in October 1991 was followed by a referendum for independence from Yugoslavia in February and March 1992, it was boycotted by the great majority of the Serbs. The turnout in the independence referendum was $63.7 \%$ and $99.4 \%$ voted for independence. $\mathrm{BiH}$ declared independence shortly afterwards in the absence of its Serb members. Following a tense period of escalating tensions and sporadic military incidents, open warfare began in Sarajevo on 6 April.

Following the declaration of independence of the Republic of $\mathrm{BiH}$, the Serbs attacked different parts of the country. The state administration of $\mathrm{BiH}$ effectively ceased to function having lost control over the entire territory and Serbs quickly assume control of over half the republic ${ }^{47}$. The Serbs wanted all lands where Serbs had a majority, eastern and western Bosnia. Slobodan Milosevic's aim was to create a Greater Serbia in territory formerly occupied by Muslims $^{48}$. The Croats aimed at securing parts of BiH habited mostly by Croats proclaiming the Croatian Republic of Herzeg-Bosnia (in Croatian - Hrvatska Republika Herceg-Bosna).

Initially, the Serb forces attacked the non-Serb civilian population in Eastern Bosnia. Once towns and villages were securely in their hands, the Serb forces - military, police, the paramilitaries and, sometimes, even Serb villagers - applied the same pattern: Bosniak houses and apartments were systematically ransacked or burnt down, Bosniak civilians were rounded up or captured, and sometimes beaten or killed in the process. Some 2.2 million refugees were displaced by the end of the war. Men and women were separated, with many of the men detained in the camps. The women were kept in various detention centres where they were mistreated in many ways including being raped repeatedly. The single most prominent example atrocity was the Srebrenica Massacre in 1995, ruled as genocide by the International Criminal Tribunal for the former Yugoslavia.

International recognition of $\mathrm{BiH}$ increased diplomatic pressure for the Yugoslav People's Army (JNA) to withdraw from the republic's territory which they officially did. However though, the Bosnian Serb members of JNA sim-

\footnotetext{
${ }^{47}$ Timeline: Bosnia-Hercegovina, (note 45).

${ }^{48}$ Kaplan L. S., NATO Divided, NATO United. The Evolution of an Alliance, Praeger, 2004, p. 116.
} 
ply changed insignia, formed the Army of Republika Srpska, and continued fighting. Armed and equipped from JNA stockpiles in Bosnia, supported by volunteers and various paramilitary forces from Serbia, and receiving extensive humanitarian, logistical and financial support from the Federal Republic of Yugoslavia, Republika Srpska's offensives in 1992 managed to place much of the country under its control. At that time the United Nations started to be involved in the situation when on 25 September 1991 the Security Council unanimously adopted its resolution 713 expressing concern at the fighting in the country and calling on all States to implement immediately a "general and complete embargo on all deliveries of weapons and military equipment to Yugoslavia" ${ }^{\prime 4}$. A month later UN Secretary-General appointed his Personal Envoy for Yugoslavia, he maintained contact with the Presidency of the European Community, with the Chairman of the CSCE-participating States, with Lord Carrington, then Chairman of the European Community's Conference on Yugoslavia, and with other interested parties. Very soon the United Nations agreed to launch a peace-keeping operation. In February 1992 the Security Council by its resolution 743 established UNPROFOR to create conditions of peace and security required for the negotiation of an overall settlement of the Yugoslav crisis within the framework of the European Community's Conference on Yugoslavia ${ }^{50}$. UNPROFOR was initially established in Croatia ${ }^{51}$. In June 1992, as the conflict intensified and extended to BiH, UNPROFOR's mandate and strength were enlarged in order to ensure the security and functioning of the airport at Sarajevo and the delivery of humanitarian aid. In September 1992, UNPROFOR's mandate was further enlarged to enable it to support efforts by the United Nations High Commissioner for Refugees to deliver humanitarian relief throughout $\mathrm{BiH}$, and to protect convoys of released civilian detainees if the International Committee of the Red Cross so requested. In addition, the Force monitored the "no-fly" zone, banning all military flights in $\mathrm{BiH}$, and the United Nations "safe areas" established by the Security Council around five Bosnian towns and the city of Sarajevo. UNPROFOR was authorized to use force in self-defence in reply to attacks against these areas, and to coordinate with NATO the use of air power in support of its activities. Similar arrangements were subsequently extended to the territory of Croatia. Still United Nations lacked means and were not prepared in 1992 to enforce its resolutions.

\footnotetext{
${ }^{49}$ United Nations Security Council, Resolution 713, http://daccessdds.un.org/doc/RESOLUTION/GEN/ NR0/596/49/IMG/NR059649.pdf?OpenElement, 20080903.

${ }^{50}$ United Nations Protection Force, http://www.un.org/Depts/dpko/dpko/co_mission/unprof_b.htm, 2008 0903.

${ }^{51}$ UNPROFOR had a mandate to ensure that the three "United Nations Protected Areas" (UNPAs) in Croatia were demilitarized. In the course of 1992, UNPROFOR's mandate was enlarged to include monitoring functions in certain other areas of Croatia (called "pink zones"); to enable the Force to control the entry of civilians into the UNPAs and to perform immigration and customs functions at the UNPA borders at international frontiers; and to include monitoring of the demilitarization of the Prevlaka Peninsula and to ensure control of the Peruca dam, situated in one of the "pink zones". In December 1992, UNPROFOR was also deployed in the former Yugoslav Republic of Macedonia, to monitor and report any developments in its border areas.
} 
European Union approach to protect civilians through UNPROFOR wasn't successful and United Nations asked NATO in 1993 to prepare a detailed plan for implementation of a non-fly zone ${ }^{52}$. On 31 March 1995, the Security Council decided to restructure UNPROFOR, replacing it with three separate but interlinked peacekeeping operations.

By 1993, when an armed conflict erupted between the predominantly Bosniak government in Sarajevo and the Croatian Republic of Herzeg-Bosnia, about $70 \%$ of the country was controlled by Republika Srpska.

In March 1994, the signing of the Washington Agreement between the leaders of the republican government and Herzeg-Bosnia led to the creation of a joint Bosniak-Croat Federation of $\mathrm{BiH}$, which absorbed the territory of the Croatian Republic of Herzeg-Bosnia and that held by the Army of the Republic of $\mathrm{BiH}$ (Bosniak's military). Despite numerous efforts by United Nations and European Union, the conflict lasted more than three years.

A NATO bombing campaign began in August, 1995, against the Army of Republika Srpska, after the Srebrenica massacre. This had together with the joint offensive by forces from Republic of Croatia and Bosniak's Armed Forces led to the military defeat of Serbian forces and close to the collapse of Republika Srpska.

In December 1995, the signing of the Dayton Peace Agreement (General Framework Agreement for Peace in Bosnia and Herzegovina/GFAP) in Dayton, Ohio by the presidents of $\mathrm{BiH}$ (Alija Izetbegović), Croatia (Franjo Tuđman), and Serbia (Slobodan Milošević) brought a halt to the fighting, roughly establishing the basic structure of the present-day state. The number of identified victims is currently at 97,207 , and the recent research estimates the total number to be less than 110,000 killed (civilians and military), and 1.8 million displaced.

Today $\mathrm{BiH}$ is a country on the Balkan peninsula of Southern Europe with an area of 51,129 square kilometres with the population of approximately 4 million $^{53}$. The country is home to three ethnic constituent nations: Bosniaks (until 1994 called Muslims), Serbs and Croats. The country is politically decentralized and comprises two governing entities, the Federation of Bosnia and Herzegovina (inhabited mostly by Bosniaks and Croats) and Republika Srpska (inhabited mostly by Serbs), with District Brčko as a de facto third entity.

As a result of the Dayton Agreement, the civilian peace implementation is supervised by the High Representative for $\mathrm{BiH}$ selected by the Peace Implementation Council, which comprises more than 50 donor countries. The High Representative has many governmental and legislative powers, including the dismissal of elected and non-elected officials. Recently, in the process of transferring part of the jurisdiction from the entities to the state, several central institutions have been established, such as defence ministry, state court, and indirect taxation service. Since March 2002 the High Representative also per-

\footnotetext{
${ }^{52}$ Kaplan, (note 48), p. 116-121.

${ }^{53}$ Timeline: Bosnia-Hercegovina, (note 45). The official census in 1991 recorded 4.4 million people, while an unofficial census in 1996 by UNHCR recorded a post-war population of 3.9 million.
} 
forms functions of the EU's Special Representative. The current HR/EUSR is Miroslav Lajcak from Slovakia, who was Ambassador to the Federal Republic of Yugoslavia (later Serbia and Montenegro), Republic of Albania and the former Yugoslav Republic of Macedonia, and later worked as Personal Representative of EU High Representative for CFSP to facilitate the Montenegrin dialogue.

The Dayton peace agreement designed the political structure of $\mathrm{BiH}$. The key common state institutions are the Presidency and the Council of Ministers.

The Chair of the Presidency of BiH rotates among three members (Bosniak, Serb, Croat), each elected as the Chair for an eight-month term within their four-year term as a member. The three members of the Presidency are elected directly by the people (Federation votes for the Bosniak/Croat, Republika Srpska for the Serb).

The Chair of the Council of Ministers is nominated by the Presidency and approved by the House of Representatives. He or she is then responsible for appointing a Foreign Minister, Minister of Foreign Trade, and others as appropriate. After elections in 2007 Nikola Spiric, a Bosnian Serb, was asked to form a government after the parties which gained the most votes agreed on a coalition. He resigned in November 2007 in protest at efforts by the High Representative and the EU Special Representative Lajcak to introduce reforms supported by the EU. Spiric said in his resignation speech that Bosnia has been run for too long by foreigners. However, in December 2007 he secured the approval of Bosnia's parliament to return as prime minister, promising to work on reforms that would bring Bosnia closer to membership of NATO and the European Union ${ }^{54}$.

The Parliamentary Assembly is the legislature body in BiH. It consists of two houses: the House of Peoples and the House of Representatives. The House of Peoples includes 15 delegates, two-thirds of which come from the Federation (5 Croat and 5 Bosniaks) and one-third from the Republika Srpska (5 Serbs). The House of Representatives is composed of 42 Members, two-thirds elected from the Federation and one-third elected from the Republika Srpska.

However, the highest political authority in the country is the High Representative in $\mathrm{BiH}$, the chief executive officer for the international civilian presence in the country. Since 1995, the High Representative has been able to bypass the elected parliamentary assembly, and since 1997 has been able to remove elected officials. International supervision is to end when the country is deemed politically and democratically stable and self-sustaining.

After Dayton agreement United Nations, NATO, OSCE started their missions in $\mathrm{BiH}$.

In December 1995 under the Dayton peace agreement NATO established NATO-led Implementation Force (IFOR) of 60,000 troops for one year to oversee implementation of the military aspects of agreement. IFOR also assisted

${ }^{54}$ Country profile: Bosnia-Hercegovina, http://news.bbc.co.uk/2/hi/europe/country_profiles/1066886.stm, 20080903. 
the OSCE in preparing, supervising and monitoring the first free elections in September 1996 and supported the Office of High Representative to assist the entities of $\mathrm{BiH}$ in building new common institutions after elections ${ }^{55}$. In sum, IFOR not only supervised how forces are withdrawn under the Agreement, but also helped to perform peace-building tasks - preparation, supervision and monitoring of elections and institutional building.

In December 1996 IFOR was replaced with 32,000 strong Stabilisation Force (SFOR), which had a task to provide stability necessary for consolidating peace. In 2003 NATO reduced the size of SFOR to 12,000 troops, but the aim remained the same. In 2004 SFOR was replaced by the military operation of the European Union - EUFOR. EUFOR acts in accordance with its peace enforcement mandate under Chapter VII of the UN Charter, which was renewed by the Security Council on 21 November 2007 (Security Council Resolution 1785). At the beginning of operation, EU deployed 7,000 troops to ensure continued compliance with the Dayton Agreement and to contribute to a safe and secure environment in $\mathrm{BiH}$. On December 2006 Council of European Union reconfigured EUFOR-Althea and today the force numbers some 2,500 troops on the ground ${ }^{56}$. The main objectives of EUFOR-Althea are to maintain a safe and secure environment in $\mathrm{BiH}$ and to ensure continued compliance with the Dayton agreement, to support the international community's High Representative/EU Special Representative for $\mathrm{BiH}$ and the local authorities. In addition, EUFOR provides support to the ICTY and relevant authorities, including support for the pursuit of persons indicted for war crimes. It also contributes to defence reform in $\mathrm{BiH}^{57}$.

As it was mentioned, in the 1995 United Nations decided to start new operation in BiH. On 21 December 1995 the Security Council passed Resolution 1035 and United Nations International Police Task Force (IPTF) and a United Nations civilian office, brought together as the United Nations Mission in $\mathrm{BiH}$ (UNMIBH). UNMIBH's mandate was to contribute to the establishment of the rule of law in $\mathrm{BiH}$ by assisting in reforming and restructuring the local police, assessing the functioning of the existing judicial system and monitoring and auditing the performance of the police and others involved in the maintenance of law and order. As Merlingen with Ostrauskaite argue at that time United Nations was the only multinational actor with expertise in the police aid field ${ }^{58}$. The same authors evaluating the work of the UN made during seven years since the deployment of mission and argue that it left authorities of $\mathrm{BiH}$ with nationally partial, under-qualified, underpaid and sometimes corrupt police officers, although the quality of police was significantly higher compared to the situation in 1995.

\footnotetext{
${ }^{55}$ NATO Handbook, Public Diplomacy Division, 2006, p. 144-145.

${ }^{56}$ European Union Council Secretariat, EU Military Operation in Bosnia and Herzegovina (Operation EUFOR-Althea), Factsheet, February 2008, http://www.consilium.europa.eu/uedocs/ cmsUpload/080220Altheaupdate10.pdf, 20080904.

${ }^{57}$ Ibid.

${ }^{58}$ Merlingen, (note 31) p. 57.
} 
Until December 2004, when operation EUFOR-Althea was launched, the EU's contribution to the peace-building process after Dayton Agreement was limited. Only in January 2003 EU launched its own Police mission - European Police Mission in BiH (EUPM), which followed on from the UN's IPTF. After EU-Balkans summit in 2003 and Brussels European Council in June 2004, Council of the European Union decided to adjust the mandate and size of the mission. Missions mandate is extended until 31 December 2009. Today 173 (147 police officers and 26 international civilians) staff from 33 countries is serving in the mission. The aim of the mission is to "under the guidance and coordination of the EUSR and as part of the broader rule of law approach in $\mathrm{BiH}$ and in the region, $\langle\ldots\rangle$ through mentoring, monitoring and inspecting, to establish in $\mathrm{BiH}$ a sustainable, professional and multiethnic police service operating in accordance with best European and international standards"59. The purpose is to be achieved through three strategic pillars:

- Support to local police in the fight against organised crime: EUPM contributes to the transformation of the State Investigation and Protection Agency (SIPA) into an operational police agency with enhanced executive powers to fight major and organised crime. EUPM is also continuously working on the development of other state-level institutions, such as the Ministry of Security and the Border Police. EUPM officers provide operational advice and support in planning and conducting investigations and operations against organised crime. EUPM also devotes particular attention to reinforcing cooperation between police and prosecutors.

- Accountability of local police: EUPM inspects and monitors police operations from the early planning stage, through investigations or operations, until the case in question reaches the court. EUPM also monitors the situation inside the police, in particular situations which are perceived as unlawful, misconducts and contrary to best practice or generally applied rules of engagement.

- Support to Police Reform Implementation: EUPM assists the political police reform process by offering legislative and technical assistance, in particular for the implementation of the April 2008 police reform laws. Its Police Reform Department works in close cooperation with its professional counterparts to identify projects aimed at developing the existing police structures, as well as enhancing their operational capacity and effectiveness ${ }^{60}$.

Merlingen with Ostrauskaite go in more details by explaining EUPM reforms, in the article only few examples will be mentioned to demonstrate the

\footnotetext{
${ }^{59}$ Council Joint Action 2005/824/CFSP of 24 November 2005 on the European Union Police Mission (EUPM) in Bosnia and Herzegovina (BiH), http://eur-lex.europa.eu/LexUriServ/LexUriServ.do?uri=OJ:L:2005:3 07:0055:0058:EN:PDF, 20080905.

${ }^{60}$ European Police Mission in Bosnia and Herzegovina, (note 56).
} 
content of peace-building operations. Organised crime was named as the biggest threat for the society and the state itself already during meetings of European Council. Mission's programme development department developed reform projects that improved the forensic assessment capabilities of the police, ensured local detectives to receive basic criminal investigation training in specific crime police areas, assisted in the establishment and operation of an IT system that connected all police departments and allowed them to use and exchange crime-related intelligence, etc. ${ }^{61}$. Another example is a project initiated in March 2004 by the EU Police Mission's press department called "Krimolovci" (crime catchers). Its anonymous, toll-free 24-hour hotline, which provide the citizens with the opportunity to share information about unsolved cases with the police. In 2007 Krimolovci calls allowed law enforcement agencies throughout the country to submit 61 cases, involving 84 persons, to prosecutors' offices. Most of these reports were related to unauthorised carrying of firearms, drugs production and dealing. In addition, 67 pieces of information were found useful for future intelligence work ${ }^{62}$. EUPM helped to implement other public campaigns: "Va a policija" ("Your Police") prompts citizens to share information with police and in such a way to enhance cooperation between citizens and police, raise awareness about police accountability; "Izaberi Život, Ne Drogu" ("Choose life, not drugs") had an aim to raise awareness about the dangers of drug abuse.

In order to enhance accountability of local police several programmes were created - The Police Education and Training Programme, Internal Affairs Programme. Educational programme focused on basic and middle management education, training on the presentation of investigative reports and training on the criminal procedure code, for example. The aim of Internal Affairs Programme was to establish transparent supervisory mechanisms in the local police forces - creation of professional standards units, public complaints bureaux, elaboration of guidelines for the functioning of these bodies ${ }^{63}$.

EU achievements of EUPM to date can be described as follows: transformation of SIPA into an operational police agency with enhanced executive powers to fight organised crime; solid development of other state-level institutions, in particular the Ministry of Security and the Border Police; development of local ownership of the police reform process through the establishment of the Police Steering Board, co-chaired by EUPM and local authorities; and progress in implementing the police reform with the mission playing a key advisory role. Stefano Recchia in article "Beyond international trusteeship: EU peacebuilding in $\mathrm{BiH}^{\prime \prime 64}$ is arguing that after Dayton Agreement country was very weak and dysfunctional and probably not have survived without international assistance. But the author claims that situation has changed only when EU started its

\footnotetext{
${ }^{61}$ Merlingen, (note 31) p. 65.

${ }^{62}$ Krimolovci, http://www.eupm.org/Details.aspx?ID=10\&TabID=8, 20080910.

${ }^{63}$ Merlingen, (note 31) p. 67.

${ }^{64}$ Recchia S., "Beyond international trusteeship: EU peace-building in Bosnia and Hercegovina", Occasional Paper No 66, February 2007, http://www.iss.europa.eu/uploads/media/occ66.pdf, 20080911.
} 
missions in $\mathrm{BiH}$ in 2003. It's involvement made state institutions self-sustaining and now $\mathrm{BiH}$ has all preconditions to become multi-ethnic democracy. On the other hand, Recchia points out that EU needs to improve effectiveness and political co-ordination of the mission on the ground and to support reforms in $\mathrm{BiH}$ after office of HR/EUSR will be closed down. Author was expecting it will happen by late 2007, but today office is still functioning.

After Dayton Agreement was signed OSCE in BiH had three main tasks - to organise, conduct and supervise elections as well as establish a permanent Election Commission, to elaborate and implement agreements on confidence - and security -building measures and regional and sub-regional arms control and to appoint a Human Rights Ombudsman and monitor the human rights situation in $\mathrm{BiH}^{65}$. Today OSCE Mission to $\mathrm{BiH}$ works on four main areas: democratization, education, human rights, and security. Work in these areas is conducted through various types of projects. In the area of democratization, OSCE is focusing on good governance, civil society and local governments. For example, it has developed special project "Ugovor" to promote local democracy by strengthening links between citizens and municipalities. In the area of good governance OSCE developed several projects, for example, it has a task to help the Parliamentary Assembly through the Parliamentary Support and the Legislative Strengthening Programmes to enhance its institutional capacity and increase public awareness of, and participation in, the legislative process. These programmes offer training and technical support. Training, orientation seminars and workshops focus on developing codes of conduct, dealing with the media, and involving citizens in parliamentary work. In the area of education, OSCE identified main problems - requirement to have schools and teaching materials free from tendentious political influence and bias - and works in developing legislation on education and making education accessible for all. For example, one of important aspects of the Interim Agreement on Returnee Children is to set criteria for school names and symbols that would be non-political. Under the Dayton Agreement OSCE is still responsible for human rights in $\mathrm{BiH}$. The organization works in the following areas: economic and social rights, judicial and legal reform, war crimes, trafficking in human beings, rights of national minorities, and strengthening national human rights institutions. The main work in the security area is related to arms control, establishment of the principle of parliamentary oversight of the armed forces and institutional building (currently main focus is to support all security sector ministries and agencies in implementing the new Security Policy Paper guidelines, which were adopted by the BiH Presidency in February 2006).

${ }^{65}$ The General Framework Agreement for Peace in Bosnia and Herzegovina, http://www.oscebih.org/ overview/gfap/eng/, 20080911. 


\section{In loco Conclusions}

Today the main stability guarantors in $\mathrm{BiH}$ are the international organizations - EU and OSCE - and the political system, created by Dayton agreement. However foreign and defence ministers of EU member states started to discuss the possibility of ending the mission in $\mathrm{BiH}$ and this can destabilise not only fragile $\mathrm{BiH}$, but all the Balkan region. As one of the evidences of such thinking can be more frequent attempts of Republika Srpska to express its wish to become independent state or join together with Serbia, especially having in mind problems related to Kosovo status. EU member states have to pay attention to the changing situation in $\mathrm{BiH}$. This problem was also raised during the visit EU Commissioner for Enlargement Olli Rehn on 10 October 2008. He and HR/EUSR Miroslav Lajcak made strong statements that BiH must stay as united country and no attempts of secession by Republika Srpska would be tolerated $^{66}$. Another problem is organised crime, which was regarded as the primary obstacle for stability in the country already after Dayton agreement was signed, but it should be noted that situation is changing too slow. At the beginning of October 2008 organised crime group exploded a bomb in shopping centre in Vitez; it's regarded as a act of organised crime ${ }^{67}$ and is a clear sign to international community the country shouldn't be left alone to deal with the problems. To end peace-building operations today is too early.

\footnotetext{
${ }^{66}$ Delegation of the European Commission to Bosnia and Herzegovina, Ollie Rehn, European Commissioner for Enlargement visited Bosnia and Herzegovina today, 10 October 2008, http://www.europa.ba/?akcija= vijesti\&akcija2=pregled\&jezik=2\&ID=317, 20081013

${ }^{67}$ Pincominfo, Za podmetanje eksploziva u FIS Vitez osumnjičen Suvad Džidić, 12 October 2008, http:// www.pincom.info/bih/opsirnije.asp?ID=60025, 20081013.
} 